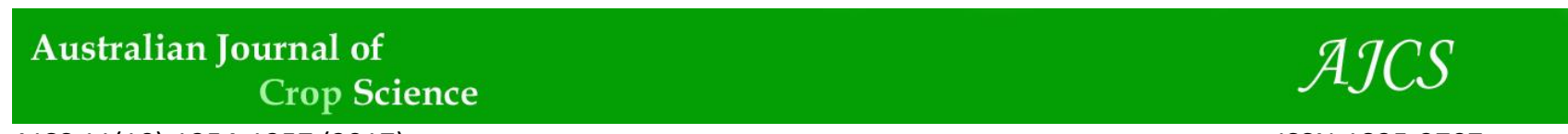

AJCS 11(10):1354-1357 (2017)

ISSN:1835-2707

doi: 10.21475/ajcs.17.11.10.pne701

\title{
Acidity neutralization and silicon availability using calcium silicate in soil cultivated with wheat (Triticum aestivum L.)
}

\author{
Luiz Antônio Zanão Júnior ${ }^{1}$, Idelvan Bonadiman Blanco², Natália Pereira ${ }^{2 *}$, Juliane Aparecida \\ Schneider $^{3}$
}

${ }^{1}$ Agronomic Institute of Paraná, IAPAR, Santa Tereza do Oeste, 85825 000, Paraná, Brazil

${ }^{2}$ Department of Agricultural Engineering, Western Paraná State University, UNIOESTE, Cascavel, 85810110, Paraná, Brazil

${ }^{3}$ Department of Agricultural Sciences, Paraná State University of Ponta Grossa, UEPG, Ponta Grossa, 84030900, Paraná, Brazil

*Corresponding author: pe.nataliaa@gmail.com

\begin{abstract}
Most tropical soils have acidity issues. The amount of corrective treatment needed to neutralize such acidity depends on the corrective material and the cultivated species. Thus, this study aimed to evaluate soil acidity neutralization by using calcium silicate $\left(\mathrm{CaSiO}_{3}\right)$, compared to calcium carbonate $\left(\mathrm{CaCO}_{3}\right)$, and the effect of increased silicon ( $\left.\mathrm{Si}\right)$ availability in soil cultivated with wheat. The treatments under analysis were: A) control (no application of corrective material); B) a calcium carbonate P.A. $\left(\mathrm{CaCO}_{3}\right)$ dose of $1.5 \mathrm{~g} \mathrm{~kg}^{-1}$; C) twice this $\mathrm{CaCO}_{3}$ dose, i.e. $3.0 \mathrm{~g} \mathrm{~kg}^{-1}$; D) calcium silicate $\left(\mathrm{CaSiO}_{3}\right)$, at the doses of 2.15 and $4.30 \mathrm{~g} \mathrm{~kg}^{-1} ;$ and E) $\mathrm{CaSiO}_{3}$ at the dose of $4.30 \mathrm{~g} \mathrm{~kg}^{-1}$ for providing the same amount of $\mathrm{Ca}$ observed with $\mathrm{CaCO}_{3}$ doses and also providing $\mathrm{Si}$, at the doses of 0.09 and $0.18 \mathrm{~g} \mathrm{~kg}^{-1}$, respectively. The experimental design was complete randomized blocks with 5 replicates. After 30-day incubation, $\mathrm{pH}$ in $\mathrm{CaCl}_{2}, \mathrm{Ca}$, hydrogen + aluminum $(\mathrm{H}+\mathrm{Al})$, and $\mathrm{Al}$ and Si content, cation-exchange capacity (CEC) at pH 7.0, and soil base saturation were measured. Plant height, number of stalks and grains per plant, dry mass and grain yield, and Si leaf content were also evaluated. Both $\mathrm{CaCO}_{3}$ and $\mathrm{CaSiO}_{3}$ were efficient in correcting acidity and increasing $\mathrm{Ca}$ content, base saturation, and $\mathrm{CEC}$ at $\mathrm{pH} 7.0$ in soil. The application of $\mathrm{CaSiO}_{3}$ has led wheat to absorb more $\mathrm{Si}$, and this provided higher grain yield and greater mass.
\end{abstract}

Keywords: Triticum aestivum L., calcium carbonate, calcium silicate.

Introduction

Most tropical agriculture soils have medium to high acidity. According to Fageria and Baligar (2001), more than 85\% of the tropical area in South American soils is acidic. Acid soils have low natural fertility, because this is associated with a small amount of calcium $(\mathrm{Ca})$, magnesium $(\mathrm{Mg})$, and potassium (K), and excessive aluminum $(\mathrm{Al})$ and manganese $(\mathrm{Mn})$, in addition to greater binding capacity of phosphorus (P) (Malavolta, 2006; Fageria and Baligar, 2008). Thus, soil acidity is associated with toxicity by $\mathrm{Al}^{3+}$ and, in some cases, by micronutrients, nutrient deficiency, decreased activity of beneficial microorganisms, and growth of the root system. All of these factors lead to lower absorption of water and nutrients (Fageria and Baligar, 2003). Good development of wheat plants takes place in low-acid soils, with corrected $\mathrm{pH}$ and at least $50 \%$ of base saturation (Souza et al., 2007).

Acidity correction is crucial for the good performance of crops, such as wheat. In order to correct it, there is application of substances that release hydroxyls $\left(\mathrm{OH}^{-}\right)$, capable of neutralizing the protons $\left(\mathrm{H}^{+}\right.$and $\left.\mathrm{Al}^{+3}\right)$ in soil solution, and this resumes the productive potential of crops (Souza et al., 2007). Ca and $\mathrm{Mg}$ carbonates, known as agricultural limestones, are the products most commonly used (Barbosa Filho et al., 2004).

$\mathrm{CaSiO}_{3}$, like agricultural limestone, is a corrective material, as it releases $\mathrm{OH}^{-}$capable of reducing soil acidity (Carvalho et al., 2000). Besides, it provides soil with silicon (Si), in the form of orthosilicic acid $\left(\mathrm{H}_{4} \mathrm{SiO}_{4}\right)$ (Marafon and Endres, 2011).

$\mathrm{Si}$ is not regarded as a crucial element for plants, because it is dispensable for their life cycle (Gocke et al., 2013). However, it is seen as a beneficial element, due to the fact that it is related to increased resistance to attack by pests and diseases; it also improves absorption and use of nutrients and decreases the stress caused by toxicity or deficiency of some elements (Ma and Yamaji, 2008; Tripathi et al., 2014). These benefits contribute to increase the yield of many crops, especially those belonging to the Poaceae family, such as wheat and rice (Rafi et al., 1997; Zanão Júnior et al., 2010). These two plants actively absorb $\mathrm{Si}$, in the form of $\mathrm{H}_{4} \mathrm{SiO}_{4}$, and accumulate it quickly (Casey et al., 2003; Ma et al., 2006).

In wheat, it was found that $\mathrm{Si}$ decreased the incidence and severity of diseases (Bélanger et al., 2003; Guével et al., 2007) and increased the resistance to pests (Dias et al., 2014), to salinity (Tuna et al., 2008), and to water deficit (Gong et al., 2005).

Both due to Si supply and acidity correction, the literature has found positive effects in applying $\mathrm{CaSiO}_{3}$ in wheat cultivation. Ahmad et al. (2007) and Sarto et al. (2015) observed that applying this corrective material promotes higher crop yield. 
In addition to other factors, the amount of corrective treatment needed to neutralize acidity depends on the corrective material and the cultivated species (Fageria and Baligar, 2008). Thus, this study aimed to evaluate the power to neutralize soil acidity by using $\mathrm{CaSiO}_{3}$, compared to $\mathrm{CaCO}_{3}$, and detect the effect of increased $\mathrm{Si}$ availability in soil cultivated with wheat.

\section{Results and discussion}

\section{Neutralization of soil acidity using $\mathrm{CaSiO}_{3}$ and $\mathrm{CaCO}_{3}$}

With no application of corrective materials, the soil had lower $\mathrm{pH}$ in $\mathrm{CaCl}_{2}$, accompanied by higher levels of $\mathrm{Al}^{3+}$ and lower levels of $\mathrm{Ca}^{2+}$, base saturation, and $\mathrm{CEC}$ at $\mathrm{pH}$ 7.0, characterizing high acidity. After 30-day incubation, these features were modified in soil samples that received corrective materials (Table 1).

$\mathrm{CaSiO}_{3}$, besides significantly increasing $\mathrm{pH}$ values, also decreased potential acidity $(\mathrm{H}+\mathrm{Al})$, neutralized the exchangeable $\mathrm{Al}$ content, and increased base saturation and soil CEC, as well as $\mathrm{CaCO}_{3}$, and this confirms its efficiency in correcting soil acidity (Table 1). Korndörfer et al. (2010), Zanão Júnior et al. (2010), and Wally et al. (2015) also found that $\mathrm{CaSiO}_{3}$ has an effect similar to $\mathrm{CaCO}_{3}$ on soil acidity correction, on CEC increase, and on improving soil chemical properties.

Among the corrective materials, the ability to neutralize $\mathrm{Al}$ was similar, in both doses used (Table 1). The smallest doses of corrective materials, $1.5 \mathrm{~g} \mathrm{~kg}^{-1}$ of $\mathrm{CaCO}_{3}$ and $2.15 \mathrm{~g} \mathrm{~kg}^{-1}$ of $\mathrm{CaSiO}_{3}$, calculated to achieve a base saturation of $50 \%$, were efficient and managed to achieve it. By applying higher doses of $\mathrm{CaCO}_{3}\left(3.0 \mathrm{~g} \mathrm{~kg}^{-1}\right)$ and $\mathrm{CaSiO}_{3}$, (4.30 $\left.\mathrm{g} \mathrm{kg}^{-1}\right)$, base saturation values of $66 \%$ and $63 \%$ were achieved, respectively. The ideal percentage of base saturation for wheat ranges from $50 \%$ to $70 \%$ (Comissão Brasileira de Pesquisa de Trigo e Triticale, 2014).

The values of $\mathrm{Ca}$ content, base saturation, and CEC at $\mathrm{pH}$ 7.0 were higher and those of potential acidity were lower when using the highest doses of $\mathrm{CaCO}_{3}$ and $\mathrm{CaSiO}_{3}$. Zanão Júnior et al. (2010) and Silva et al. (2014) also found that $\mathrm{CaSiO}_{3}$ was as efficient as $\mathrm{CaCO}_{3}$ in increasing $\mathrm{Ca}$ content and $\mathrm{pH}$ in soil. The higher the dose of corrective materials used, the higher the amount of $\mathrm{Ca}$ and proton-neutralizing materials added, according to Souza et al. (2007).

\section{Silicon content}

In soil samples where $\mathrm{CaSiO}_{3}$ was applied as a corrective material, Si content increased when compared to the other treatments, because this element was solubilized and released, corroborating the findings of Ramos et al. (2006), Pereira et al. (2007), and Korndörfer et al. (2010). No difference was observed between $\mathrm{CaSiO}_{3}$ doses used to increase $\mathrm{Si}$ content in soil and the latter increased to 18.17 and $28.21 \mathrm{mg} \mathrm{dm}^{-3}$, respectively, for the doses of 2.15 and $4.30 \mathrm{~g} \mathrm{~kg}^{-1}$. In both cases, $\mathrm{Si}$ content in soil increased to exceed the critical level of $9.8 \mathrm{mg} \mathrm{dm}^{-3}$, recommended by Korndörfer et al. (1999) for rice cultivation.

The plants receiving the $\mathrm{CaSiO}_{3}$ treatment, at its lowest dose, accumulated about $4.2 \mathrm{~g} \mathrm{~kg}^{-1}$ more $\mathrm{Si}$ in the leaves when compared to those that did not receive it. When the highest dose was applied, the average difference was $8.8 \mathrm{~g}$ $\mathrm{kg}^{-1}$ of Si. Such results corroborate Sarto et al. (2014), who reported significantly increased values for $\mathrm{Si}$ concentration in wheat leaves and stalks by applying $\mathrm{CaSiO}_{3}$. Lima Filho and Tsai (2007) and Zanão Júnior et al. (2010) also observed greater $\mathrm{Si}$ absorption by wheat when fertilized with this element. According to Lima Filho and Tsai (2007), wheat is highly efficient in absorbing $\mathrm{Si}$, becoming bigger in soils with high content of this element, and it is regarded as a $\mathrm{Si}$ accumulating plant (Gocke et al., 2013). Data demonstrate that wheat absorbed this element and, along with other factors, it has led to improved plant growth, resulting in a more efficient grain yield.

\section{Yield compounds}

Regarding wheat, plant height and number of stalks were not different in terms of doses and corrective material. Sarto et al. (2015), applying $\mathrm{CaSiO}_{3}$ doses to grow the wheat crop, found no significant differences in these variables.

The number of grains per plant, as well as dry mass and grain yield, were higher by applying $\mathrm{CaSiO}_{3}$ (Table 2). Applying $2.15 \mathrm{~g} \mathrm{~kg}^{-1}$ of $\mathrm{CaSiO}_{3}$ to soil led to a $31 \%$ increase in the number of grains per plant and a $39 \%$ increase in dry mass and grain yield when compared to the control. In wheat cultivation by applying Si to soil, Zanão Júnior et al. (2010) observed an improved plant architecture, providing more upright leaves. Si, by enabling more upright leaves, provides greater leaf exposure to the sun (Epstein, 1999); this increases the photosynthetic rate and, as a consequence, leads to higher grain yield. Tavares et al. (2014) observed a 15\% increase in wheat grain yield due to silicon fertilization. Just as the number of grains, applying silicate to the crop's soil led to increased weight. Mauad et al. (2003) and Toledo et al. (2012) also reported that $\mathrm{Si}$ fertilization significantly increased the mass of wheat grains. Perhaps this was due to the beneficial effect of Si for the crop, since the leaf content of this element also increased under this condition (Table 2).

\section{Materials and methods}

\section{Experimental design and treatments}

The experiment was conducted in a greenhouse. The treatments under analysis were: A) control (no application of corrective material); B) a calcium carbonate P.A. $\left(\mathrm{CaCO}_{3}\right)$ dose of $1.5 \mathrm{~g} \mathrm{~kg}^{-1}$; C) twice this $\mathrm{CaCO}_{3}$ dose, i.e. $3.0 \mathrm{~g} \mathrm{~kg}^{-1}$; D) calcium silicate (CaSiO3) at the dose of $2.15 \mathrm{~g} \mathrm{~kg}-1$ and E) $\mathrm{CaSiO} 3$ at the dose of $4.30 \mathrm{~g} \mathrm{~kg}-1$. These doses of $\mathrm{CaSiO}_{3}$ provides the same amount of $\mathrm{Ca}$ added with doses of $\mathrm{CaCO}_{3}$, but also provide $\mathrm{Si}$, at the doses of 0.09 and $0.18 \mathrm{~g} \mathrm{~kg}^{-1}$ in the treatments $\mathrm{D}$ and $\mathrm{E}$, respectively. The amount of $\mathrm{Ca}$ provided was $0.6 \mathrm{~g} \mathrm{~kg}^{-1}$ for the lowest doses of corrective materials evaluated and $1.2 \mathrm{~g} \mathrm{~kg}^{-1}$ for the highest ones. The experimental design was five replicate randomized blocks. $\mathrm{CaCO}_{3}$ has $56 \%$ of calcium oxide $(\mathrm{CaO})$ and it does not have $\mathrm{Si}$ in its composition. $\mathrm{CaSiO}_{3}$ has $39 \%$ of $\mathrm{CaO}$, in addition to $4.5 \%$ of $\mathrm{Si}$ (soluble).

\section{Soil characteristics}

The samples consisted in a dystrophic Red Latosol (dRL), with a clayish texture (49\% of clay), low natural fertility, and low $\mathrm{Si}$ content available. They were collected at 0-30 cm depth and sieved through a $2 \mathrm{~mm}$ mesh, showing these chemical features: $\mathrm{pH}\left(\mathrm{CaCl}_{2}\right)=4.10$; carbon $(\mathrm{C})$ (WalkleyBlack $)=18.10 \mathrm{~g} \mathrm{dm}^{-3} ; \mathrm{P}($ Mehlich-1 $)=1.9 \mathrm{mg} \mathrm{dm}^{-3} ; \mathrm{H}+\mathrm{Al}$ $=7.20 \mathrm{cmol}_{\mathrm{c}} \mathrm{dm}^{-3} ; \mathrm{K}\left(\right.$ Mehlich-1) $=0.25 \mathrm{cmol}_{\mathrm{c}} \mathrm{dm}^{-3} ; \mathrm{Ca}=$ $0.35 \mathrm{cmol}_{\mathrm{c}} \mathrm{dm}^{-3} ; \mathrm{Mg}=0.55 \mathrm{cmol}_{\mathrm{c}} \mathrm{dm}^{-3} ; \operatorname{vanadium}(\mathrm{V})=$ $14 \%$; iron $(\mathrm{Fe})=65 \mathrm{mg} \mathrm{dm}^{-3}$; $\operatorname{copper}(\mathrm{Cu})=0.8 \mathrm{mg} \mathrm{dm}^{-3} ; \mathrm{Mn}$ $=19.2 \mathrm{mg} \mathrm{dm}^{-3}$; zinc $(\mathrm{Zn})=21.2 \mathrm{mg} \mathrm{dm}^{-3}$; and $\mathrm{Si}\left(\mathrm{CaCl}_{2}\right)=4$ $\mathrm{mg} \mathrm{dm}{ }^{-3}$. 
Table 1. $\mathrm{pH}$ values in $\mathrm{CaCl}_{2}$ and $\mathrm{Al}, \mathrm{H}+\mathrm{Al}, \mathrm{Ca}$ content, $\mathrm{CEC}$ at $\mathrm{pH} 7.0(\mathrm{~T})$, base saturation (V), and $\mathrm{Si}$ in soil due to doses and sources of corrective material added, after 30-day incubation.

\begin{tabular}{lccccccc}
\hline Acidity corrective materials & $\begin{array}{c}\mathrm{pH} \\
\left(\mathrm{CaCl}_{2}\right)\end{array}$ & $\mathrm{Al}$ & $\mathrm{H}+\mathrm{Al}$ & $\begin{array}{c}\mathrm{Ca} \\
----\mathrm{cmol}_{\mathrm{c}} \mathrm{dm}^{-3}---------\end{array}$ & $\begin{array}{c}\mathrm{T} \\
\%\end{array}$ & $\begin{array}{c}\mathrm{Si} \\
\mathrm{mg} \mathrm{dm}^{-3}\end{array}$ \\
\hline Control & $4.10 \mathrm{c}$ & $1.05 \mathrm{a}$ & $5.35 \mathrm{a}$ & $0.40 \mathrm{c}$ & $6.46 \mathrm{c}$ & $16 \mathrm{c}$ & $5.03 \mathrm{~b}$ \\
$\mathrm{CaCO}_{3}\left(1.50 \mathrm{~g} \mathrm{~kg}^{-1}\right)$ & $5.05 \mathrm{~b}$ & $0.00 \mathrm{~b}$ & $4.46 \mathrm{~b}$ & $3.71 \mathrm{~b}$ & $8.89 \mathrm{~b}$ & $50 \mathrm{~b}$ & $5.23 \mathrm{~b}$ \\
$\mathrm{CaCO}_{3}\left(3.00 \mathrm{~g} \mathrm{~kg}^{-1}\right)$ & $5.80 \mathrm{a}$ & $0.00 \mathrm{~b}$ & $3.24 \mathrm{c}$ & $5.44 \mathrm{a}$ & $9.41 \mathrm{a}$ & $66 \mathrm{a}$ & $5.07 \mathrm{~b}$ \\
$\mathrm{CaSiO}_{3}\left(2.15 \mathrm{~g} \mathrm{~kg}^{-1}\right)$ & $5.03 \mathrm{~b}$ & $0.00 \mathrm{~b}$ & $4.28 \mathrm{~b}$ & $3.43 \mathrm{~b}$ & $8.59 \mathrm{~b}$ & $50 \mathrm{~b}$ & $18.17 \mathrm{a}$ \\
$\mathrm{CaSiO}_{3}\left(4.30 \mathrm{~g} \mathrm{~kg}^{-1}\right)$ & $5.70 \mathrm{a}$ & $0.00 \mathrm{~b}$ & $3.18 \mathrm{c}$ & $5.31 \mathrm{a}$ & $9.32 \mathrm{a}$ & $63 \mathrm{a}$ & $28.21 \mathrm{a}$ \\
\hline $\mathrm{CV} \%$ & 4.12 & 14.04 & 6.43 & 3.67 & 6.65 & 4.54 & 10.76 \\
\hline
\end{tabular}

Mean values followed by different letters in the column differ at $5 \%$ probability by Tukey test.

Table 2. Plant height (PH), number of stalks per plant (SPP), number of grains per plant (GPP), dry mass and grain yield per plant (DMYGPP), and Si leaf content (SiLC), due to doses and sources of correction material added to the soil, after 30-day cultivation.

\begin{tabular}{lccccc} 
& $\begin{array}{c}\text { PH } \\
\mathrm{cm}\end{array}$ & SPP & GPP & $\begin{array}{c}\text { DMYGP } \\
\mathrm{g}\end{array}$ & $\begin{array}{c}\text { SiLC } \\
\mathrm{g} \mathrm{kg}^{-1}\end{array}$ \\
\hline $\mathrm{Control}$ & $57.0 \mathrm{a}$ & $4.9 \mathrm{a}$ & $205.3 \mathrm{~b}$ & $4.28 \mathrm{~b}$ & $8.9 \mathrm{~b}$ \\
$\mathrm{CaCO}_{3}\left(1.5 \mathrm{~g} \mathrm{~kg}^{-1}\right)$ & $63.0 \mathrm{a}$ & $5.1 \mathrm{a}$ & $211.3 \mathrm{~b}$ & $4.61 \mathrm{~b}$ & $9.4 \mathrm{~b}$ \\
$\mathrm{CaCO}_{3}\left(3.0 \mathrm{~g} \mathrm{~kg}^{-1}\right)$ & $60.9 \mathrm{a}$ & $5.1 \mathrm{a}$ & $209.3 \mathrm{~b}$ & $3.90 \mathrm{~b}$ & $9.2 \mathrm{~b}$ \\
$\mathrm{CaSiO}_{3}\left(2.15 \mathrm{~g} \mathrm{~kg}^{-1}\right)$ & $61.9 \mathrm{a}$ & $6.1 \mathrm{a}$ & $268.5 \mathrm{a}$ & $5.93 \mathrm{a}$ & $13.3 \mathrm{a}$ \\
$\mathrm{CaSiO}_{3}\left(4.30 \mathrm{~g} \mathrm{~kg}^{-1}\right)$ & $59.9 \mathrm{a}$ & $6.0 \mathrm{a}$ & $253.5 \mathrm{a}$ & $4.89 \mathrm{a}$ & $17.9 \mathrm{a}$ \\
\hline $\mathrm{CV} \%$ & 7.65 & 14.56 & 13.78 & 15.65 & 12.67 \\
\hline
\end{tabular}

Mean values followed by different letters in the column differ at $5 \%$ probability by Tukey test.

\section{Conduction of experiment}

Initially, a mass equivalent to the soil volume of $3.0 \mathrm{dm}^{3}$, for each pot, was weighed and placed in plastic bags with a capacity of $5 \mathrm{dm}^{3}$, for providing soil acidity correction. The treatments, corresponding to doses of corrective materials, were added to soil dried at air. After soil homogenization with corrective materials, deionized water was added, in order to raise humidity to $80 \%$ of the field capacity, with a subsequent 30-day incubation period. After incubation, 400 $\mathrm{mg} \mathrm{kg}^{-1}$ of $\mathrm{P}\left(\mathrm{CaHPO}_{4}\right)$ were added, incorporated to the entire soil volume. From these samples, $50 \mathrm{~g}$ of soil were taken away, at each experimental plot, for chemical characterization. Si content was determined after extraction using $\mathrm{CaCl}_{2}$ (Korndörfer et al., 2004), as well as $\mathrm{pH}$ in $\mathrm{CaCl}_{2}$, $\mathrm{Ca}$ content, $\mathrm{H}+\mathrm{Al}, \mathrm{Al}, \mathrm{CEC}$ at $\mathrm{pH} 7.0$, and base saturation, according to Pavan (1992).

After removing the soil samples, sowing was done at $1 \mathrm{~cm}$ depth, distributing 8 seeds per pot of the wheat cultivar IPR 144.

The first thinning was performed 5 days after emergence (DAE), leaving 6 plants per pot. Then, the first application of nitrogen $(\mathrm{N})$ and micronutrients was done, and the only applications of $\mathrm{K}$ and sulfur (S). The second thinning was performed 10 DAE, leaving 4 plants per pot. The second and third plots of nitrogen fertilization and micronutrients were performed, respectively, 15 and 30 DAE. Fertilization was conducted using nutrient solutions, always applying the volume of $50 \mathrm{~mL} \mathrm{dm}{ }^{-3}$. Soil moisture in the pot was maintained around $80 \%$ of the field capacity, using deionized water. The total amount of nutrients applied in fertilization (in $\mathrm{mg} \mathrm{kg}^{-1}$ ), was: $\mathrm{N}=160 ; \mathrm{K}=210 ; \mathrm{S}=60 ; \mathrm{Mg}=60$; boron (B) $=1 ; \mathrm{Cu}=1.5 ; \mathrm{Fe}=2 ; \mathrm{Mn}=3.5 ;$ molybdenum $(\mathrm{Mo})=$ 0.2 ; and $\mathrm{Zn}=5$. The salts used were: $\mathrm{NH}_{4} \mathrm{NO}_{3}, \mathrm{CO}\left(\mathrm{NH}_{2}\right)_{2}$, $\mathrm{KCl}, \mathrm{K}_{2} \mathrm{SO}_{4}, \mathrm{MgSO}_{4}, \mathrm{H}_{3} \mathrm{BO}_{3}, \mathrm{CuSO}_{4} .5 \mathrm{H}_{2} \mathrm{O}, \mathrm{FeSO}_{4} .7 \mathrm{H}_{2} \mathrm{O}$, $\mathrm{MnCl}_{2} \cdot 4 \mathrm{H}_{2} \mathrm{O},\left(\mathrm{NH}_{4}\right)_{6} \mathrm{Mo}_{7} \mathrm{O}_{24} \cdot 4 \mathrm{H}_{2} \mathrm{O}$, and $\mathrm{ZnSO}_{4} \cdot 7 \mathrm{H}_{2} \mathrm{O}$.

\section{Traits measured}

At the end of the crop cycle, there was evaluation of plant height, number of stalks and grains per plant, dry mass and grain yield, and Si leaf content.
Plant height was determined in all harvested plants, measuring the distance between the base of the plant and the stalk insertion. The number of stalks and grains per plant were determined at harvest. Then, the grains were dried in an oven with air circulation at $65^{\circ} \mathrm{C}$, until reaching constant mass. After harvesting, the leaves were washed using distilled water, neutral detergent solution, $1 \mathrm{~mL} \mathrm{~L}^{-1}, \mathrm{HCl} 0.1$ $\mathrm{mol} \mathrm{L}{ }^{-1}$, and distilled water again. After superficial washing, they underwent drying in a forced-air circulation oven at $65^{\circ} \mathrm{C}$, until reaching a constant weight. Once dried, they were processed in a Wiley mill, using a $0.84 \mathrm{~mm}$ mesh. Si leaf content was determined through the alkaline digestion method and dosage was determined through the colorimetric method (Korndörfer et al., 2004).

\section{Statistical analysis}

This experiment was conducted twice and data for each variable were grouped, because the homogeneity of variance was confirmed by the Cochran test (Gomez and Gomez, 1984). Data underwent analysis of variance (ANOVA), through the Statistical and Genetic Analysis System (SAEG), and the average values were compared using Tukey test $(p=$ $0.05 \%)$

\section{Conclusion}

Soil acidity correction and increased $\mathrm{Ca}$ content can be provided both by $\mathrm{CaCO}_{3}$ and $\mathrm{CaSiO}_{3}$. The number of grains per plant, Si leaf content, and dry mass yield of wheat grains were higher by applying $\mathrm{CaSiO}_{3}$. The beneficial effect of using $\mathrm{CaSiO}_{3}$ as soil acidity corrective and calcium supply has a positive consequence for soil fertility. Furthermore, the silicon provided by application of $\mathrm{CaSiO}_{3}$ on soil increases the wheat crop quality and yield.

\section{Acknowledgments}

The authors thank anonymous reviewers for their insightful comments on the original manuscript and the Brazilian Coordination for the Improvement of Higher Education Personnel (CAPES) for its research funding. 


\section{References}

Ahmad F, Iah R, Aziz T, Maqsood A, Tahir MA, Kanwal S (2007) Effect of silicon application on wheat (Triticum aestivum L.) grown under water deficiency stress. Emir J Food Agric. 19:1-7.

Barbosa Filho M P, Zimmermann FJP, Silva OF (2004) Influência da escória silicatada na acidez do solo e na produtividade de grãos do arroz de terras altas. Cienc e Agrotec. 28:323-331.

Bélanger RR, Benhamou N, Menzies JG (2003) Cytological evidence of an active role of silicon in wheat resistance to powdery mildew (Blumeria graminis f. sptritici). Phytopathology. 93:402-412.

Carvalho R, Furtini Neto AE, Curi N, Fernandes LA, Oliveira Jr AC (2000) Dessorção de fósforo por silício em solos ácidos. Rev Bras Cienc Solo. 24:69-74.

Casey WH, Kinrade SD, Knight CTG, Rains DW, Epstein E (2003) Aqueous silicate complexes in wheat, Triticum aestivum L. Plant Cell Environ. 27:51-54.

Comissão brasileira de pesquisa de trigo e triticale. Informações técnicas para trigo e triticale - safra 2015 / VIII Reunião da Comissão Brasileira de Pesquisa de Trigo e Triticale (2014) Embrapa. p 229.

Dias PAS, Sampaio MV, Rodrigues MP, Korndörfer AP, Oliveira RS, Ferreira SE, Korndörfer GH (2014) Induction of resistance by silicon in wheat plants to alate and apterous morphs of Sitobion avenae (Hemiptera: Aphididae). Environ Entomol. 43:949-956.

Epstein E (1999) Silicon. Annu Rev Plant Phys. 50:641-664.

Fageria NK, Baligar VC (2001) Lowland rice response to nitrogen fertilization. Commun Soil Sci Plant Anal. 32:1405-1428.

Fageria NK, Baligar VC (2003) Fertility management of tropical acid soil for sustainable crop production. In: Rengel Z (ed) Handbook of soil acidity. Marcel Dekker. 359-385.

Fageria NK, Baligar VC (2008) Ameliorating soil acidity of tropical Oxisols by liming for sustainable crop production. Adv Agron. 99:345-431.

Gocke M (2013) Silicon uptake by wheat: Effects of Si pools and pH. J Plant Nutr Soil Sc. 176:551-560.

Gomez KA, Gomez AA (1984) Statistical procedures for agricultural research. John Wiley, 2rd edn. p 680.

Gong H, Zhu X, Chen K, Wang S, Zhang C (2005) Silicon alleviates oxidative damage of wheat plants in pots under drought. Plant Sci. 169:313-321.

Guével MH, Menzies, JG, Bélanger, RR (2007) Effect of root and foliar applications of soluble silicon on powdery mildew control and growth of wheat plants. Eur J Plant Pathol. 119:119-130.

Korndörfer GH, Arantes VA, Corrêa GF, Snyder GH (1999) Efeito do silicato de cálcio no teor de silício e na produção de grãos de arroz de sequeiro. Rev Bras Cienc Solo. 23:635419.

Korndörfer GH, Pereira, HS, Nolla A (2004) Análise de silício: solo, planta e fertilizante. Uberlândia: Grupo de Pesquisa em Silício, ICIAG-Universidade Federal de Uberlândia. p 28.

Korndörfer GH, Silva GC, Teixeira IR, Silva AG, Freitas RS (2010) Efeito da adubação silicatada sobre gramíneas forrageiras e características químicas do solo. Pesq Agropecu Trop. 40:119-125.

Lima filho OF, Tsai SM (2007) Crescimento e produção do trigo e da aveia branca suplementados com silício. Embrapa Agropecuária Oeste. p 34. (Boletim de Pesquisa e Desenvolvimento 14).
Ma JF, Tamai K, Yamaji N, Mitani N, Konish S, Katsuhara M, Ishiguro M, Mirata Y, Yano M (2006) A silicon transporter in rice. Nat. 440:688-691.

Ma JF, Yamaji N (2008) Functions and transport of silicon in plants. Cell Mol Life Sci. 65:3049-3057.

Malavolta E (2006) Manual de nutrição mineral de plantas. Livroceres. $\mathrm{p} 638$.

Marafon AC, Endres L (2011) Adubação silicatada em canade-açúcar. Embrapa Tabuleiros Costeiros. p 48. (Embrapa Tabuleiros Costeiros. Documentos 165).

Mauad M, Crusciol CAC, Grassi Filho H, Corrêa JC (2003) Nitrogen and silicon fertilization of upland rice. Sci Agr. 60:761-765.

Pavan MA (1992) Manual de análise química do solo e controle de qualidade. IAPAR. p 40. (Circular técnica 76).

Pereira HS, Barbosa NC, Carneiro MAC, Korndörfer GH (2007) Avaliação de fontes e extratores de silício no solo. Pesq Agropecu Bras. 42:239-247.

Rafi MM, Epstein E, Falk RH (1997) Silicon deprivation causes physical abnormalities in wheat (Triticum aestivum L.). Plant Soil. 211:223-230.

Ramos LA, Nolla A, Korndörfer GH, Pereira HS, Camargo MS (2006) Reatividade de corretivos da acidez e condicionadores de solo em colunas de lixiviação. Rev Bras Cienc Solo. 30:849-857.

Sarto MVM, Lana MC, Rampim L, Rosset JS, Wobeto JR (2015) Efeitos da aplicação de silicato na fertilidade do solo e rendimento do trigo. Semina-Cienc Agrar. 36:40714082.

Sarto MVM, Rampim L, Lana MC, Rosset JS, Ecco M, Wobeto JR (2014) Atributos químicos do solo e desenvolvimento da cultura do trigo em função da adubação silicatada. R Agrarian. 7:390-400.

Silva WB, Barcelos FP, Sichocki D, Silva GMC (2014) Uso do silicato de cálcio na correção da acidez do solo e no desenvolvimento da Brachiaria ruziziensis L. Perspec online Exa Eng. 10:1-11.

Souza DMG, Miranda LN, Oliveira AS (2007) Acidez do solo e sua correção. In: Novais RF, V Alvarez VH, Barros NF, Fontes RLF, Cantarutti RB, Neves JCL (eds) Fertilidade do solo. Sociedade Brasileira de Ciência do Solo. 205-274.

Tavares LC, Fonseca DAR, Rufino CA, Oliveira S, Brunes AP, Villela FA (2014) Adubação silicatada em trigo: rendimento e qualidade de sementes. Rev Fac Agron 113:94-99.

Toledo MZ, Castro GSA, Crusciol CAC, Soratto RP, Cavariani C, Ishizuka MS, Picoli LB (2012) Silicon leaf application and physiological quality of white oat and wheat seeds. Semina-Cienc Agrar. 33:19693-1702.

Tripathi DK, Singh VP, Gangwar S, Prasad SM, Maurya JN, Chauhan DK (2014) Role of silicon in enrichment of plant nutrients and protection from biotic and abiotic stresses. In: Ahmad P (ed) Improvement of crops in the era of climatic changes. Springer. 39-56.

Tuna AL, Kaya C, Higgs D, Murillo-Amador B, Aydemir S, Girgin AR (2008) Silicon improves salinity tolerance in wheat plants. Environ Exp Bot. 62:10-16.

Wally MS, Bissani CA, Santos VP, Bortolon L, Bortolon ESO, Andreazza R, Gianello C (2015) Correção da acidez do solo e aporte de metais pesados pela aplicação de escoria básica de aciaria. Biosci J. 31:135-145.

Zanão Júnior LA, Fontes RLF, Coelho PHM, Korndörfer GH, Zambolim L (2010) Soil-applied silicon decreases severity of wheat spot blotch on silicon-deficient soils. Rev Bras Cienc Solo. 34:401-408. 